Репродуктивные технологии, физиология развития

УДК 636.2:591.465.12:576:576.3/.7.086.83:591.04

doi: 10.15389/agrobiology.2020.4.784rus

\title{
ФУНКЦИОНАЛЬНАЯ АКТИВНОСТЬ МИТОХОНДРИЙ И СТАТУС ХРОМАТИНА НАТИВНЫХ И ДЕВИТРИФИЦИРОВАННЫХ ООЦИТОВ Bos taurus ПОД ВОЗДЕЙСТВИЕМ НАНОЧАСТИЦ ВЫСКОДИСПЕРСНОГО КРЕМНЕЗЕМА *
}

\author{
Т.И. КУЗЬМИНАํㅛ, И.В. ЧИСТЯКОВАํㅛ, Д.Н. ТАТАРСКАЯ 2
}

Митохондрии - единственные клеточные компартменты, генерирующие и трансформирующие энергию в клетке. На изменение экстра- и внутриклеточных условий (ионный гомеостаз, степень дегидратации, температура) эти органеллы реагируют одними из первых. При обработке сверхнизкими температурами вследствие перекисного окисления липидов нарушается работа АТФсинтетазного комплекса (Е.А. Новодержкина с соавт., 2016), а также структура генетического материала. В качестве цитопротекторных соединений могут быть предложены наночастицы высокодисперсного кремнезема (нВДК). Аморфная форма диоксида кремния, или высокодисперсный кремнезем, проявляющий свою биологическую активность через высокую адсорбирующую способность, снижает концентрацию ионов и биополимеров во время дегидратации клетки при криоконсервации (Т.Т. Туров с соавт., 2011). В настоящей работе впервые показано, что при использовании наночастиц высокодисперсного кремнезема в концентрации $0,001 \%$ в технологии витрификации и экстракорпорального созревания девитрифицированных ооцитов (ДВ) коров наблюдается повышение митохондриального потенциала ДВ ооцитов и снижение числа дегенерированных клеток. Цель исследования - идентифицировать характер воздействия наночастиц высокодисперсного кремнезема на функциональную активность митохондрий и статус хроматина в нативных и девитрифицированных ооцитах коров при экстракорпоральном созревании. В экспериментах использовали ооцит-кумулюсные комплексы (ОКК) голштинизированного крупного рогатого скота (Bos taurus). Витрификации подвергались ооциты с гомогенной цитоплазмой, окруженные пятью и более слоями кумулюсных клеток. ОКК, предназначенные для витрификации, обрабатывали тремя растворами криопротекторных агентов (КПА), приготовленными на среде Т-199 с добавлением $10 \%$ сыворотки крови плодов коров (FBS, «НуClone», Великобритания). В состав растворов КПА для витрификации ооцитов в контроле входили: в КПА-1 - 0,7 М диметилсульфоксид (DMSO) и 0,9 М этиленгликоль (EG); KПА-2 - 1,4 M DMSO и 1,8 M EG; KПА-3 - 2,8 M DMSO, 3,6 М EG и 0,65 М трегалоза. Растворы КПА, растворы для девитрификации и отмывания ооцитов в опыте дополняли наночастицами высокодисперсного кремнезема (нВДК, 4-17 нм, массовая концентрация $0,001 \%$ ), синтезированными посредством высокотемпературного гидролиза. В контроле нативные и девитрифицированные ооциты культивировали в течение 24 ч при 38,5 ${ }^{\circ}$ и $90 \%$ влажности, в атмосфере, содержащей $5 \%$ СО2. Среда имела следующий состав: Т-199 $+10 \%$ FBS $+10^{6}$ клеток/мл гранулезы +50 нг/мл бычьего пролактина. Для культивирования нативных и девитрифицированных ооцитов в опыте в эту среду добавляли нВДК (массовая концентрация $0,001 \%)$. Для оценки функционального состояния митохондрий в нативных и ДВ ооцитах использовали зонд MitoTracker Orange CMTMRos («Thermo Fisher Scientific», Великобритания). В серии экспериментов по выявлению воздействия нВДК на ядерное созревание женских гамет ооциты помещали на 5-10 мин в 0,9 \% раствор цитрата натрия и с помощью препаровальной иглы механически очищали от кумулюса. Затем клетки переносили на сухое обезжиренное стекло и фиксировали смесью метанол:уксусная кислота (3:1). Суховоздушные препараты окрашивали азур-эозином по Романовскому-Гимзе. При воздействии нВДК в ДВ ооцитах возрастала интенсивность флуоресценции MitoTracker Orange CMTMRos $(77 \pm 6,3$ против $169 \pm 12,8$ мкA, p < 0,05). Функциональная активность митохондрий ДВ ооцитов, обработанных нВДК, в период от стадии диплотены до стадии метафазы I увеличилась с $169 \pm 12,8$ до 181 $\pm 7,7$ мкА (р < 0,05), в дальнейшем происходило ее снижение до 141 $\pm 11,2$ мкА, что, вероятно, связано с завершением ядерно-цитоплазматического созревания ооцитов. При оценке статуса хроматина ДВ ооцитов в группе, обработанной нВДК, было отмечено снижение числа клеток с признаками дегенерации хроматина на стадии диплотены и метафазы II по сравнению с интактными ДВ ооцитами (40 против $21 \%$ и 59 против $38 \%, \mathbf{p}<0.01)$, что, возможно, обусловлено процессами репарации ДНК. В целом выявлен положительный эффект 0,001 \% нВДК в отношении показателей функциональной активности митохондрий и статуса хроматина в ДВ женских гамет Bos taurus.

Ключевые слова: ооцит, витрификация, наночастицы высокодисперсного кремнезема, функциональная активность митохондрий, MitoTracker Orange CMTMRos, хроматин, Bos taurus. * Работа выполнена в соответствии с темой проекта № 18-016-00147А, финансируемого Российским Фондом
Фундаментальных исследований (РФФИ). 
Совершенствование криопротекторных сред для витрификации ооцитов посредством введения различных соединений, необходимых для сохранения жизнеспособности после процедуры размораживания, продолжает оставаться актуальной проблемой технологии криоконсервации. В последнее время при создании комбинированных криоконсервантов широко применяются биологически активные вещества с наноразмерной структурой, синтезированные из различных соединений микроэлементов и минералов, например гидроксиапатита (НА), диоксида кремния $\left(\mathrm{SiO}_{2}\right)$, оксида алюминия $\left(\mathrm{Al}_{2} \mathrm{O}_{3}\right)$ и диоксида титана $\left(\mathrm{TiO}_{2}\right)(1,2)$. Включение наночастиц в состав криопротекторных агентов повышает эффективность витрификации за счет увеличения теплопроводности витрифицирующих растворов и снижения последствий рекристаллизационных процессов, наблюдаемых при размораживании клеток с использованием смесей стандартных криопротекторных агентов, таких как этиленгликоль и диметилсульфоксид $(1,2)$.

Высокодисперсный (пирогенный) кремнезем (ВДК) - аморфная форма диоксида кремния с рассеянием размеров сферической формы частиц 4-17 нм (90 \% интервала) (3). Ввиду выраженной адсорбционной активности, обусловленной значительной удельной поверхностью $\left(\mathrm{S}_{\mathrm{yд.}}=200 \mathrm{~m}^{2} /\right.$ г), наночастицы ВДК способны снижать концентрацию полимеров и ионов во время дегидратации клетки $(3,4)$, а также связывать внеклеточную воду (5). При этом большой размер агрегатов тонкодисперсного кремнезема и малая плотность частиц в этих агломератах обеспечивают связывание значительного количества внеклеточной воды, которая не подвержена изменениям при взаимодействиях с клетками, в том числе в процессах замораживания/оттаивания (5).

В условиях оксидативного стресса при замораживании наблюдается денатурирующее влияние свободно-радикальных процессов на ион-транспортирующие белки, нарушение синтеза ДНК и образования термотропных дефектов митохондрий, что в конечном счете приводит к гибели клеток (6). Митохондрии обеспечивают клетку АТФ, необходимой для завершения мейотического созревания. Особенности их функционирования детерминируют качество гаметы $(7,8)$. Аномалии преобразования хроматина ядра клетки при температурозависимом окислительном стрессе главным образом обусловлены нарушением биосинтеза ядерных белков и их связи с ДНК, разрушением нуклеотидов, одно- и двухнитевыми разрывами ДНК (9).

В настоящей работе впервые показано, что при использовании наночастиц высокодисперсного кремнезема в концентрации 0,001 \% в технологии витрификации и экстракорпорального созревания девитрифицированных ооцитов (ДВ) коров повышается митохондриальный потенциал ДВ ооцитов и снижается число дегенерированных клеток.

Цель исследования - идентифицировать характер воздействия наночастиц высокодисперсного кремнезема на функциональную активность митохондрий и статус хроматина в нативных и девитрифицированных ооцитах коров при экстракорпоральном созревании.

Методика. В экспериментах использовали ооцит-кумулюсные комплексы (OKK) голштинизированного крупного рогатого скота (Bos taurus). Яичники коров после овариоэктомии доставляли в лабораторию в растворе $0,9 \% \mathrm{NaCl}$, содержащем пенициллин (100 МЕ/мл), стрептомицин (100 мкг/мл) и амфотерицин В (0,25 нг/мл), при температуре $30-35{ }^{\circ} \mathrm{C}$. ОКК аспирировали из фолликулов диаметром 3-8 мм.

Витрификации подвергались ооциты с гомогенной цитоплазмой, окруженные пятью и более слоями кумулюсных клеток. ОКК, предназначенные для витрификации, обрабатывали тремя растворами криопротек- 
торных агентов (КПА), приготовленными на среде Т-199 с добавлением $10 \%$ fetal bovine serum (FBS, «НуClone», Великобритания). В состав растворов КПА для витрификации ооцитов в контроле (без обработки наночастицами высокодисперсного кремнезема - нВДК) входили: в КПА-1 0,7 М диметилсульфоксид (DMSO) и 0,9 М этиленгликоль (EG); в KПА-2 1,4 M DMSO и 1,8 M EG; в КПА-3 - 2,8 M DMSO, 3,6 M EG и 0,65 M трегалоза (Trehalose). Все использованные реагенты, за исключением специально обозначенных в тексте, произведены компанией «Sigma-Aldrich» (США), пластиковая лабораторная посуда - BD Falcon ${ }^{\mathrm{TM}}$ (Becton Dickinson and Co., BD Biosciences», США). В опыте в растворы КПА для витрификации ооцитов вносили нВДК (4-17 нм, массовая концентрация 0,001\%), синтезированные в ИХП им. А.А. Чуйко НАН Украины посредством высокотемпературного гидролиза. Наночастицы ВДК использовали в виде стабильной суспензии, состоящей преимущественно из субмикронных агрегатов. При выборе концентрации основывались на данных, представленных разработчиками (10).

ОКК помещали на 30 с в КПА-1, затем на 30 с в КПА-2 и на 20 с в КПА-3. После этого пайеты с ооцитами погружали в сосуды Дьюара с жидким азотом. ОКК извлекали из пайет не ранее, чем через 1 ч, размораживали, последовательно помещая в 0,25 М раствор трегалозы, приготовленный на среде Т-199 с добавлением $10 \%$ FBS $\left(3\right.$ мин, $\left.37^{\circ} \mathrm{C}\right), 0,19 \mathrm{M}$ раствор трегалозы $\left(3 \mathrm{мин,} 37^{\circ} \mathrm{C}\right)$ и $0,125 \mathrm{M}$ раствор трегалозы $\left(3 \mathrm{Mин,} 37^{\circ} \mathrm{C}\right)$, после чего трижды отмывали в среде Т-199 с 10 \% FBS. В контроле перечисленные растворы не содержали нВДК, в опыте их дополняли нВДК с конечной концентрацией $0,001 \%$.

Нативные и девитрифицированные (ДВ) ооциты культивировали в течение 24 ч при $38,5{ }^{\circ} \mathrm{C}$ и $90 \%$ влажности в атмосфере, содержащей $5 \%$ $\mathrm{CO}_{2}$ в среде следующего состав: Т-199 + $10 \%$ FBS $+10^{6}$ клеток/мл гранулезы +50 нг/мл бычьего пролактина. При культивировании нативных и девитрифицированных ооцитов в контроле эта среда не содержала нВДК, в опыте - к ней добавляли нВДК с массовой концентрацией 0,001 \% (11).

Для оценки функционального состояния митохондрий в нативных и ДВ ооцитах на разных стадиях мейоза использовали зонд MitoTracker Orange CMTMRos («Thermo Fisher Scientific», Великобритания). OKК по 1520 шт. помещали в капли 500 нМ раствора MitoTracker Orange CMTMRos объемом 500 мкл и инкубировали 30 мин в темноте при температуре $37{ }^{\circ} \mathrm{C}$. Затем ооциты отмывали от красителя в фосфатном буферном растворе (ФБР) с добавлением 0,3 \% бычьего сывороточного альбумина. Отмытые ооциты очищали от кумулюсных клеток, инкубируя в 0,1 \% растворе трипсина при $37^{\circ} \mathrm{C}$ в течение 5-10 мин, переносили в раствор Хенкса, содержащий 3,7 \% параформальдегида, а затем фиксировали 15 мин при $37^{\circ} \mathrm{C}$. После фиксации ооциты отмывали от параформальдегида в ФБР и помещали на стекла Super frost в капли раствора Hoechst 33258 (2,5 мкг/мл, «Thermo Fisher Scientific», Великобритания).

Измерение интенсивности флуоресценции (ИФ) MitoTracker Orange CMTMRos и оценку ядерного созревания с использованием красителя Hoechst 33258 проводили с помощью флуоресцентного микроскопа ZEISS Axio Lab.A1 и фотометрической насадки («Karl Zeiss», Германия). Длина волн возбуждения для MitoTracker Orange CMTMRos составляла 554 нм, излучения - 576 нм; для Hoechst 33258 - соответственно 352 нм и 461 нм. ИФ MitoTracker Orange CMTMRos измеряли в мкA.

В серии экспериментов по выявлению влияния нВДК на ядерное 
созревание женских гамет ооциты помещали на 5-10 мин в 0,9\% раствор цитрата натрия и с помощью препаровальной иглы механически очищали от кумулюса. Затем клетки переносили на сухое обезжиренное стекло и фиксировали смесью метанол: уксусная кислота (3:1). Суховоздушные препараты окрашивали азур-эозином по Романовскому-Гимзе.

Результаты обрабатывали методом двухфакторного (two-way) дисперсионного анализа ANOVA с помощью пакета статистической программы SigmaStat («Jandel Scientific Software», США). Результаты представлены в виде средних значений $(M)$ и стандартных ошибок средних ( $\pm \mathrm{SEM})$. Для оценки достоверности различий между сравниваемыми средними значениями использовали $t$-критерий Стьюдента и критерий $\chi^{2}$ Пирсона с поправкой на правдоподобие. Значимость различий сравниваемых средних значений оценивали при $\mathrm{p}<0,05, \mathrm{p}<0,01$ и $\mathrm{p}<0,001$ для 3-5 независимых экспериментов.

Результаты. Ранее мы выявили положительное влияние 0,001 \% нВДК на статус хроматина соматических клеток овариальных фолликулов коров (12), характер ооцит-кумулюсных взаимодействий при созревании женских гамет (13), развитие доимплантационных эмбрионов (11). В настоящем исследовании было обнаружено, что введение в состав криопротекторных сред нВДК обусловливало повышение показателей флуоресценции зонда MitoTracker Orange CMTMRos в ДВ ооцитах по сравнению с гаме-

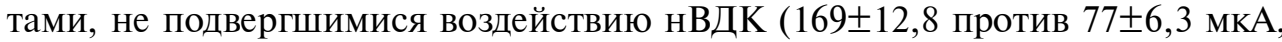
$\mathrm{p}<0,05)$ (табл., рис. 1).

Интенсивность флуоресценции (мКА) зонда MitoTracker Orange CMTMRos («Thermo Fisher Scientific», Великобритания) в нативных и девитрифицированных ооцитах голштинизированных коров на разных стадиях мейоза при воздействии наночастиц высокодисперсного кремнезема (нВДК) ( $M \pm \mathrm{SEM}$, число экспериментов -5 , общее число ооцитов -529 , культура in vitro)

\begin{tabular}{|c|c|c|c|c|c|}
\hline \multirow[t]{2}{*}{ Группа } & \multirow{2}{*}{$\begin{array}{l}\text { Обработка } \\
\text { нВДК }\end{array}$} & \multirow{2}{*}{$\begin{array}{l}\text { Число } \\
\text { ооцитов }\end{array}$} & \multicolumn{3}{|c|}{$\begin{array}{l}\text { Интенсивность флуоресценции MitoTracker Orange } \\
\text { CMTMRos на соответствующей стадии мейоза }\end{array}$} \\
\hline & & & диплотена & метафаза I & метафаза II \\
\hline \multirow[t]{2}{*}{ Нативные ооциты } & - & 133 & $331 \pm 16,2^{\mathrm{a}}$ & $188 \pm 11,3^{\mathrm{e}}$ & $143 \pm 10,1^{\mathrm{i}}$ \\
\hline & + & 139 & $309 \pm 15,6^{b}$ & $203 \pm 11,8^{\mathrm{f}}$ & $149 \pm 14,7^{j}$ \\
\hline \multirow{2}{*}{$\begin{array}{l}\text { Девитрифицированные } \\
\text { ооциты }\end{array}$} & - & 128 & $77 \pm 6,3^{c}$ & $139 \pm 11,7 \mathrm{~g}$ & $101 \pm 9,7 \mathrm{k}$ \\
\hline & + & 129 & $169 \pm 12,8^{d}$ & $181 \pm 7,7^{\mathrm{h}}$ & $141 \pm 11,2^{1}$ \\
\hline
\end{tabular}
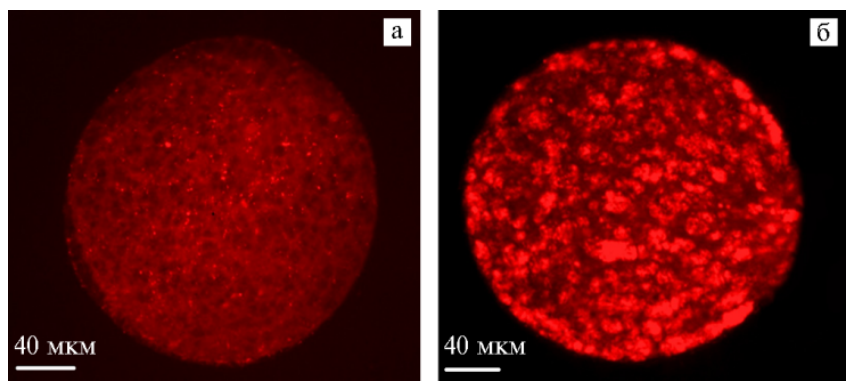

Рис. 1. Репрезентативное изображение митохондрий в девитрифицированных ооцитах голштинизированных коров на стадии диплотены с низкой (а) и высокой (б) интенсивностью флуоресценции зонда MitoTracker Orange MTMRos («Thermo Fisher Scientific», Великобритания): a - ооциты, не обработанные наночастицами высокодисперсного кремнезема (нВДК), б ооциты, обработанные $0,001 \%$ нВДК (культура in vitro; микроскоп ZEISS Axio Lab.A1, «Karl Zeiss», Германия).
Через 14 ч (после достижения девитрифицированными ооцитами стадии метафазы I) в присутствии нВДК мы отмечали статистически значимые различия в показателях ИФ MitoTracker Orange CMTMRos между клетками, обработанными и не подвергшимися действию нВДК $(181 \pm 7,7$

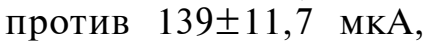
$\mathrm{p}<0,05)$. При этом к моменту достижения ооцитами стадии метафазы I ИФ нативных ооцитов 
не отличалась от показателя ДВ ооцитов, подвергшихся обработке нВДК

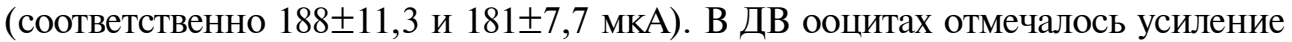
активности митохондрий со стадии диплотены до метафазы I (p < 0,05) (см. табл.). На завершающих этапах созревания гамет наблюдали общее снижение ИФ MitoTracker Orange CMTMRos во всех исследуемых группах, а показатели митохондриальной активности были минимальными.

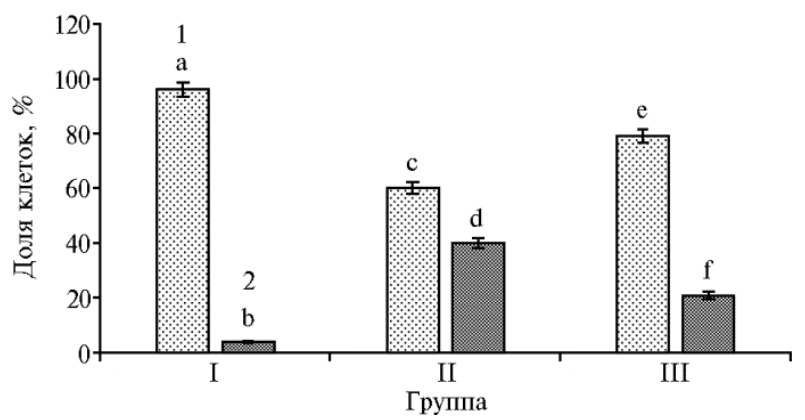

Рис. 2. Доля ооцитов голштинизированных коров с нормальным (1) и дегенерированным (2) хроматином на стадии диплотены при воздействии наночастиц высокодисперсного кремнезема (нВДК): I - нативные ооциты (контроль), II девитрифицированные ооциты (контроль), III - девитрифицированные ооциты, обработанные $0,001 \%$ нВДК. Вертикальные отрезки - стандартные ошибки средних значений $( \pm \mathrm{SEM})$ (0 ч культивирования, число ооцитов 293, число экспериментов - 4; культура in vitro).

Различия в парах статистически значимы: для a:b; a:c; e:f; b:d; b:f; a:d; a:f; c:b; c:f; e:b; d:e — при p <0,001; для c:d; c:e; d:f — при $\mathrm{p}<0,01$ (критерий $\chi^{2}$ Пирсона).

При оценке состояния хроматина нативных и ДВ ооцитов на стадии диплотены выявили повышение доли ДВ интактных гамет с признаками дегенерации хромосом по сравнению с клетками, обработанными нВДК (40 против $21 \%$, $\mathrm{p}<0,01)$ (рис. 2). При последующем культивировании до стадии метафазы I мы не обнаружили значимых различий в количестве ооцитов с нормальным или дегенерированным хроматином между контрольной и обработанными нВДК нативными и ДВ группами гамет (рис. 3, А).

A

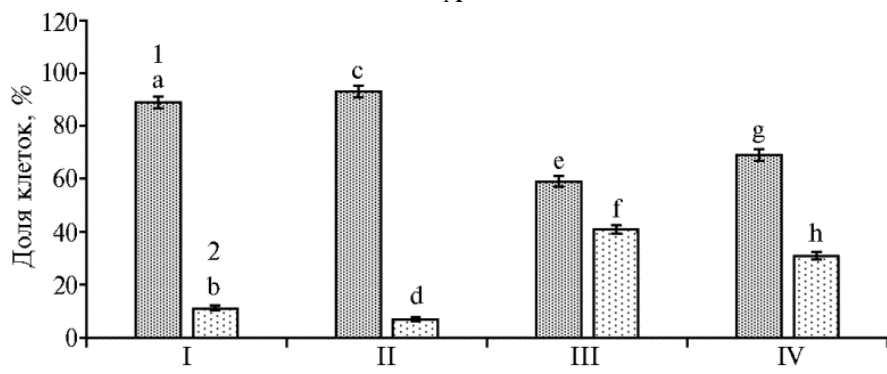

Б

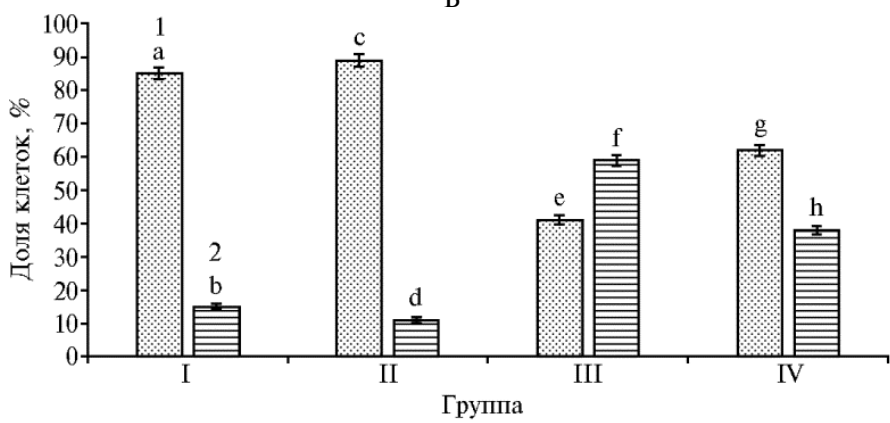

Рис. 3. Доля ооцитов голштинизированных коров с нормальным (1) и дегенерированным (2) хроматином на стадиях метафазы I (А) и метафазы II (Б) при культивировании с наночастицами высокодисперсного кремнезема (нВДК): I - нативные ооциты (контроль), II - нативные ооциты, обработанные $0,001 \%$ нВДК, III - девитрифицированные ооциты (контроль), IV - девитрифицированные ооциты, обработанные 0,001 \% нВДК. Вертикальные отрезки - стандартные ошибки средних значений $( \pm \mathrm{SEM})$ (24 ч культивирования, число ооцитов -419 , 
A: a:b; c:d; g:h; a:e; a:g; c:e; c:g; b:f; b:h; d:f; d:h; a:d; a:f; a:h; c:b; c:f; c:h; e:b; e:d; e:h; g:b; g:d; g:f — различия в парах статистически значимы при р $<0,001$; различия е:f статистически значимы при р $<0,01$. Б: a:b; c:d; g:h; a:e; a:g; c:e; c:g; b:f; b:h; d:f; d:h; a:d; a:f; a:h; c:b; c:f; c:h; e:b; e:d; g:b; g:d — различия в парах статистически значимы при р $<0,001$; e:g; f:h - различия в парах статистически значимы при $\mathrm{p}<0,01$; e:f - различия статистически значимы при $\mathrm{p}<0,05$ (критерий $\chi^{2}$ Пирсона).
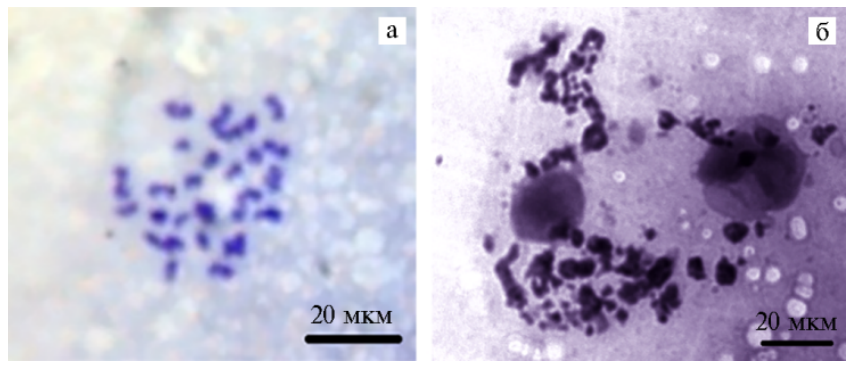

Рис. 4. Репрезентативное изображение нормального (а) и дегенерированного (б) хроматина на стадии метафазы II в девитрифицированных ооцитах голштинизированных коров при обработке наночастицами высокодисперсного кремнезема $(0,001 \%)$ ( культура in vitro; цитогенетический препарат, окрашивание азур-эозином по Романовскому-Гимзе; микроскоп ZEISS Axio Lab.A1, «Karl Zeiss», Германия). лено нарушением не только работы антиоксидантной системы, но и образованием неселективных митохондриальных пор (МП) $(7,14)$. Витрификация индуцирует изменения в кальциевых рецепторах на мембране эндоплазматического ретикулума, приводящие к атипичной флуктуации содержания $\mathrm{Ca}^{2+}$, что вызывает нерегулируемое открытие МП (15). При такой спонтанной пермеабилизации мембраны происходит запуск каскада событий апоптоза (7). Полученные нами результаты позволяют предположить, что нВДК оптимизирует процессы, связанные с кальциевой регуляцией функционирования МП и усилением ионообмена между цитоплазмой клетки (3, 6). Оксидативный стресс митохондрий при криоконсервации связан с окислительной модификацией белков (16) и образованием белковых фибриллярных комплексов $(17,18)$. Эти процессы провоцируют окисление клеточной мембраны, нарушают ионный гомеостаз, функционирование ядерного аппарата, меж- и внутриклеточную передачу сигналов (18). Ранее было показано, что наночастицы размером от 3 до 9 нм, проявляющие свойства квантовых точек, способны тормозить образования продуктов окисления белков (16) и ингибировать формирование агрегатных белковых структур $(17,19)$. Ультрамалые частицы кремнезема предположительно обладают антиоксидантным и антиагрегационным эффектами, за счет чего происходит сохранение клеточных функций, в том числе функций ядерного аппарата. Также следует отметить, что влияние нВДК на митохондрии клеток может быть обусловлено концентрацией частиц в растворе $(20,21)$. Увеличение функциональной активности митохондрий в обработанных нВДК и контрольных ДВ ооцитах при переходе от стадии диплотены к стадии метафазы I, возможно, объясняется восстановлением электрохимического градиента и повышенной продукцией АТФ (22), необходимой для завершения ядерно-цитоплазматического созревания ДВ ооцита.

Наночастицы ВДК не оказывают генотоксичного действия (23) и способны инициировать антистрессовый ответ клеток на действие сверхнизких температур через активацию белков репарации ДНК $(24,25)$. Важно отметить, что нВДК в отношении генотоксичности, как и в случае с цито- 
токсичностью, обладают размеро- и дозозависимым эффектом $(25,26)$. В наших опытах воздействие нВДК оказывало положительный эффект на ядерное созревание ДВ ооцитов, что, вероятно, было связано с индукцией антистрессового ответа и ослаблением последствий окислительного стресса, обусловленными ультрамалыми размерами частиц ВДК и их небольшой концентрацией в средах для созревания.

Наблюдаемый эффект снижения митохондриальной активности во всех исследованных группах при культивировании, может быть следствием завершения ядерно-цитоплазматического созревания ооцита с дальнейшим блоком мейоза на стадии метафазы II перед активацией яйцеклетки сперматозоидом. Однако уменьшение ИФ MitoTracker Orange CMTMRos и увеличение доли клеток с дегенерированным хроматином в группе ДВ ооцитов на стадии метафазы II по сравнению с другими экспериментальными группами, по-видимому, свидетельствует также о значительном количестве криоповреждений в структуре митохондрий и хроматина.

Таким образом, при экстракорпоральном созревании девитрифицированных ооцитов коров было выявлено повышение митохондриального потенциала ДВ ооцитов и снижение числа дегенерированных клеток при воздействии наночастиц высокодисперсного кремнезема, что может свидетельствовать об усилении ионообменных и репарационных процессов. Увеличение митохондриальной активности при достижении ДВ ооцитами стадии метафазы I указывает на усиление энергоснабжения клеток в этот период. Общее снижение трансмембранного потенциала в нативных и ДВ ооцитах на стадии метафазы II может быть связано либо с завершением ядерно-цитоплазматического созревания, либо с наличием большого количества криоповреждений в структуре митохондрий (мембранах) и хроматина. Следовательно, использование при витрификации женских гамет Bos taurus 0,001 \% нВДК положительно влияет на показатели ядерно-цитоплазматического созревания ДВ ооцитов. Проблема создания криобанка ооцитов приобретает особую актуальность в условиях крупномасштабной селекции и снижения репродуктивных качеств высокопродуктивных коров для сохранения генофонда элитных особей и конструирования новых генотипов, в том числе с использованием технологии CRISPR-Cas9. Полученные нами данные могут быть использованы при совершенствовании этапов экстра- и интраовариальной витрификации ооцитов других видов животных, в том числе и при решении проблем бесплодия у человека.

\section{ЛИТЕРАТУРА}

1. Xu H.F., Hao B.T., Liu L.J., Tang L.L., Liu B.L. Calorimetric studies on thermal properties of nano-cryoprotectant solutions during vitrification. CryoLetters, 2016, 37(6): 406-410.

2. Li W., Zhou X., Dai J., Zhang D., Liu B., Wang H., Xu L. Effect of hydroxyapatite nanoparticles on MII-stage porcine oocytes vitrification and the study of its mechanism. Biochemical Engineering Journal, 2013, 30(4): 789-793.

3. Туров В.В., Барвинченко В.Н., Крупская Т.В., Гунько В.М., Чехун В.Ф. Гидратные свойства композитного материала на основе высокодисперсного кремнезема и ДНК. Біотехнологія, 2011, 4(4): 34-48.

4. Rubio L., Pyrgiotakis G., Beltran-Huarac J., Zhang Y., Gaurav J., Deloid G., Spyrogianni A., Sarosiek K., Bello D., Demokritou P. Safer-by-design flame-sprayed silicon dioxide nanoparticles: the role of silanol content on ROS generation, surface activity and cytotoxicity. Particle and Fibre Toxicology, 2019, 16(1): 40 (doi: 10.1186/s12989-019-0325-1).

5. Галаган Н.П., Гунько В.М., Порхун Н.Г., Новикова Е.А., Туров В.В. Влияние дисперсности нанокремнеземов на их биоактивность по отношению к гаметам быка. Доповіді Національної академії наук України, 2012, 5: 126-133. 
6. Савченко Д.С. Изучение антиоксидантных свойств нанокомпозита высокодисперсного кремнезема с наночастицами серебра. Медицина и образование в Сибири, 2013, 6: 23-30.

7. Al-Zubaidi U., Liu J., Cinar O., Robker R.L., Adhikari D., Carroll J. The spatio-temporal dynamics of mitochondrial membrane potential during oocyte maturation. Molecular Human Reproduction, 2019, 25(11): 695-705 (doi: 10.1093/molehr/gaz055).

8. Пожилова Е.В., Новиков В.Г., Левченкова О.С. Регуляторная роль митохондриальной поры и возможности ее фармакологической модуляции. Обзоры по клинической фармакологии и лекарственной терапии, 2014, 12(3): 13-19.

9. Yoon S.Y., Eum J.H., Cha S.K., Yoon T.K., Lee D.R., Lee W.S. Prematuration culture with phosphodiesterase inhibitors after vitrification may induce recovery of mitochondrial activity in vitrified mouse immature oocytes. Biopreservation and Biobanking, 2018, 16(4): 296-303 (doi: 10.1089/bio.2018.0010).

10. Galagan N.P., Klymenko N.Y., Orel I.L., Novikova E.A., Turov V.V. Biofunctional nanomaterials based on ultra-fine silica, protein and aminocarbohydrates. Biopolymers and Cell, 2010, 26(3): 205-213 (doi: 10.7124/bc.000158).

11. Chistyakova I.V., Kuzmina T.I., Stanislavovich T.I., Kovtun S.V. Effects of highly dispersed silica nanoparticles on the cryoresistance of the bovine cumulus-oocyte complexes. Cryobiology, 2018, 85: 176 (doi: 10.1016/j.cryobiol.2018.10.215).

12. Кузьмина Т.И., Чистякова И.В. Влияние наночастиц высокодисперсного кремнезема на апоптоз в нативных и девитрифицированных клетках гранулезы Bos taurus. Aктуальные вопросы ветеринарной биологии, 2019, 3(43): 8-12 (doi: 10.24411/2074-5036-2019-10031).

13. Кузьмина Т.И., Станиславович Т.И., Молчанов А.В. Влияние наночастиц высокодисперсного кренезема на показатели криорезистентности девитрифицированных ооцит-кумулюсных комплексов Bos taurus. Аграрный научный ж⿻рнал, 2019, 3: 29-34 (doi: 10.28983/asj.y2019i3pp29-34).

14. Новодережкина Е.А., Животовский Б.Д., Гогвадзе В.Г. Индукция неспецифической проницаемости митохондриальной мембраны и ее роль в гибели клеток. Молекулярная биология, 2016, 50(1): 51-68 (doi: 10.7868/S002689841601016X).

15. Kim B., Yoon S.-Y., Cha S.K., Kwak K.H., Fissore R.A., Parys J.B., Yoon T.K., Lee D.R. Alterations in calcium oscillatory activity in vitrified mouse eggs impact on egg quality and subsequent embryonic development. Pflügers Archiv - European Journal of Physiology, 2011, 461: 515-526 (doi: 10.1007/s00424-011-0955-0).

16. Mostek A., Słowińska M., Judycka S., Karol H., Ciereszko A., Dietrich M.A. Identification of oxidatively modified proteins due to cryopreservation of carp semen. Journal of Animal Science, 2018, 96(4): 1453-1465 (doi: 10.1093/jas/sky063).

17. Xiao L., Zhao D., Chan W.-H., Choi M.M.F., Li H.-W. Inhibition of beta 1-40 amyloid fibrillation with N-acetyl-L-cysteine capped quantum dots. Biomaterials, 2010, 31(1): 91-98 (doi: 10.1016/j.biomaterials.2009.09.014).

18. Shin W.S., Di J., Cao Q., Li B., Seidler P.M., Murray K.A., Bitan G., Jiang L. Amyloid $\beta$ protein oligomers promote the uptake of tau fibril seeds potentiating intracellular tau aggregation. Alzheimers Research and Therapy, 2019, 11(1): 86 (doi: 10.1186/s13195-019-0541-9).

19. Sukhanova A., Poly S., Bozrova S., Lambert E., Ewald M., Karaulov A., Molinari M., Nabiev I. Nanoparticles with a specific size and surface charge promote disruption of the secondary structure and amyloid-like fibrillation of human insulin under physiological conditions. Frontiers in Chemistry, 2019, 7: 480-486 (doi: 10.3389/fchem.2019.00480).

20. Desai J., Foresto-Neto O., Honarpisheh M., Steiger S., Nakazawa D., Popper B., Buhl E.M., Boor P., Mulay S.R., Anders H.-J. Particles of different sizes and shapes induce neutrophil necroptosis followed by the release of neutrophil extracellular trap-like chromatin. Scientific Reports, 2017, 7(1): 15003 (doi: 10.1038/s41598-017-15106-0).

21. Sun L., Li Y., Liu X., Jin M., Zhang L., Du Z., Guo C., Huang P., Sun Z. Cytotoxicity and mitochondrial damage caused by silica nanoparticles. Toxicology in Vitro, 2011, 25(8): 1619-1629 (doi: 10.1016/j.tiv.2011.06.012).

22. Barros V.R.P., Monte A.P.O., Santos J.M.S., Lins T.L.B.G., Cavalcante A.Y.P, Gouveia B.B., Müller M.C., Oliveira Junior J.L., Barberino R.S., Donfack N.J., Araújo V.R., Matos M.H.T. Effects of melatonin on the in vitro growth of early antral follicles and maturation of ovine oocytes. Domestic Animal Endocrinology, 2019, 71: 106386 (doi: 10.1016/j.domaniend.2019.106386).

23. Савченко Д.С. Изучение генотоксичности и цитотоксичности нанокомпозита высокодисперсного кремнезема с наночастицами серебра. Вестник новых медицинских технологий, 2013, 20(4): 44-47.

24. Yang Y., Du X., Wang Q., Liu J., Zhang E., Sai L., Peng C., Lavin M.F., Yeo A.J., Yang X., Shao H., Du Z. Mechanism of cell death induced by silica nanoparticles in hepatocyte cells is by apoptosis. International Journal of Molecular Medicine, 2019, 44(3): 903-912 (doi: 10.3892/ijmm.2019.4265). 
25. Murugadoss S., Lison D., Godderis L., Van Den Brule S., Mast J., Brassinne F., Sebaihi N., Hoet P.H. Toxicology of silica nanoparticles: an update. Archives of Toxicology, 2017, 91(9): 29673010 (doi: 10.1007/s00204-017-1993-y).

26. Li Y., Duan J., Chai X., Yang M., Wang J., Chen R., Sun Z. Microarray-assisted size-effect study of amorphous silica nanoparticles on human bronchial epithelial cells. Nanoscale, 2019, 11(47): 22907-22923 (doi: 10.1039/c9nr07350g).

\author{
${ }^{1}$ Всероссийский НИИ генетики и разведения \\ сельскохозяйственных жмивотных, \\ филиал ФГБНУ ФНЦ животноводства - \\ ВИЖ им. академика Л.К. Эрнста, \\ 196601 Россия, г. Санкт-Петербург-Пушкин, Московское ш., 55А, \\ e-mail: prof.kouzmina@mail.ru, itjerena7@gmail.com $₫$; \\ ${ }^{2}$ ГАОУ ВО ЛО Ленинградский государственный \\ университет им. А.С. Пушкина, \\ 196605 Россия, Санкт-Петербург, г. Пушкин, ш. Петербургское, 10, \\ e-mail: dianatatarskaa587@gmail.com
} Поступила в редакцию

Sel'skokhozyaistvennaya biologiya [Agricultural Biology], 2020, V. 55, № 4, pp. 784-793

\title{
THE INFLUENCE OF HIGHLY DISPERSED SILICA NANOPARTICLES ON THE FUNCTIONAL ACTIVITY OF MITOCHONDRIA AND CHROMATIN STATE IN NATIVE AND DEVITRIFIED Bos taurus OOCYTES
}

\author{
T.I. Kuzmina ${ }^{1}$, I.V. Chistyakova ${ }^{1}$, D.N. Tatarskaya ${ }^{2}$
}

\author{
${ }^{1}$ All-Russian Research Institute for Farm Animal Genetics and Breeding - branch of Ernst Federal Science Center for \\ Animal Husbandry, 55A, Moskovskoe sh., St. Petersburg-Pushkin, 196625 Russia, e-mail prof.kouzmina@mail.ru, \\ itjerena7@gmail.com (corresponding author $\triangle$ ); \\ 2Pushkin Leningrad State University, 10, Petersburg Sh., St. Petersburg-Pushkin, 196605, e-mail dianata- \\ tarskaa587@gmail.com \\ ORCID: \\ Kuzmina T.I. orcid.org/0000-0002-4218-6080 \\ Chistyakova I.V. orcid.org/0000-0001-7229-5766 \\ Tatarskaya D.N. orcid.org/0000-0002-8834-1912 \\ The authors declare no conflict of interests \\ Acknowledgements: \\ The work was performed according to the theme of the project No. 18-016-00147A funded by the Russian Foun- \\ dation for Basic Research. \\ Received May 28, 2020 \\ doi: 10.15389/agrobiology.2020.4.784eng
}

\section{Abstract}

Mitochondria are the only cellular compartments which generate and transform energy in the cell. These organelles are among the first to respond to changes in extra- and intracellular conditions (e.g., ionic homeostasis, dehydration level, temperature). Exposition to ultra-low temperatures, due to lipid peroxidation, causes ATP synthetase disorders and destruction of genetic material (E.A. Novocherkina et al., 2016). Highly dispersed silica nanoparticles (nHDS) can be proposed as cytoprotectors. An amorphous form of silicon dioxide, or highly dispersed silica, which exhibits its biological activity through high adsorption capacity, reduces the concentration of ions and biopolymers upon cell dehydration during cryopreservation, thus preventing a sharp change in the osmolar equilibrium between the intra- and extracellular environment (T.T. Turov et al., 2011). This paper deals with the first report of the increase in cryoresistance and maturation rate of donor Bos taurus oocytes due to exposure to nHDS during vitrification and in vitro culture, which ensures higher functional activity of mitochondria and preserves structural properties of chromatin of native and devitrified (DV) oocytes. The study aimed to identify the impact of nHDS on functional activity of mitochondria and chromatin state of cows' native and devitrified oocytes during in vitro culture. In the experiments, we used oocytecumulus complexes (OCCs) of Holsteinized cows. The oocytes with homogeneous cytoplasm surrounded by five or more layers of cumulus cells were subjected to vitrification. OCCs intended for vitrification were successively exposed to three solutions of cryoprotective agents (CPAs) based on T-199 medium with $10 \%$ fetal bovine serum (FBS, HyClone, Great Britain), the CPA-1 containing $0.7 \mathrm{M}$ dimethyl sulfoxide (DMSO) + 0.9 M ethylene glycol (EG) (for $30 \mathrm{~s})$, CPA-2 (1.4 M DMSO + 1.8 M EG (for $30 \mathrm{~s}$ ), and CPA-3 (2.8 M DMSO + 3.6 M EG + 0.65 M trehalose) (for $20 \mathrm{~s}$ ). The oocytes in straws were plunged into liquid nitrogen. After thawing, the oocytes were washed with T-199 medium containing $0.25 \mathrm{M}, 0.19 \mathrm{M}$, and $0.125 \mathrm{M}$ trehalose, and finally with 
T-199 medium. In the test group of oocytes, highly dispersed silica nanoparticles (nHDS, 4-17 nm, mass concentration $0.001 \%$ ) synthesized by high-temperature hydrolysis were added to the CPAs, devitrification solutions and washing solutions. In the control group, native and devitrified oocytes were cultured for 24 hours in maturation medium, the T-199 with $10^{6}$ granulosa cells $/ \mathrm{ml}$ supplemented with $10 \%$ fetal bovine serum and $50 \mathrm{ng} / \mathrm{ml}$ bovine prolactin $\left(38.5{ }^{\circ} \mathrm{C}, 90 \%\right.$ humidity, and $5 \% \mathrm{CO}_{2}$ atmosphere). In the test group, the maturation medium for native and devitrified oocytes was supplemented with nHDS at a final concentration of $0.001 \%$. Mitochondrial activity was measured by fluorescence intensity (FI) of MitoTracker Orange CMTMRos (Thermo Fisher Scientific, UK) in $\mu \mathrm{A}$. In a series of experiments on identification of the nHDS effects on the nuclear maturation of female gametes, oocytes were exposed for 5-10 min to $0.9 \%$ sodium citrate solution and mechanically released from cumulus cells with a preparation needle. Then the cells were placed on a glass slide and fixed with methanol:acetic acid solution (3:1). The dry-air preparations were stained with azure-eosin by Romanovsky-Giemsa method. In DV oocytes influenced by nHDS, the FI of MitoTracker Orange CMTMRos probe increased from $77 \pm 6.3 \mu \mathrm{A}$ to $169 \pm 12.8 \mu \mathrm{A}(\mathrm{p}<0.05)$. The functional activity of mitochondria of DV oocytes treated with nHDS increased from $169 \pm 12.8 \mu \mathrm{A}$ to $181 \pm 7.7 \mu \mathrm{A}$ $(\mathrm{p}<0.05)$ during the diplotene to the metaphase I stages, and subsequently decreased to $141 \pm 11.2 \mu \mathrm{A}$ at metaphase II stage, what is probably associated with the completion of nuclear and cytoplasmic maturation of oocytes. When assessing the chromatin state of oocytes in the nHDS-treated group, we revealed a decrease in the number of oocytes with chromatin degeneration at diplotene and metaphase II stages compared to those in the nHDS-untreated DV oocytes (40\% vs. $21 \%$, and $59 \%$ vs. $38 \%, \mathrm{p}<0.01)$, that is probably associated with the DNA repair. In general, our findings reveal a positive effect of nHDS on the functional activity of mitochondria and the chromatin state in DV female gametes of Bos taurus. The obtained results expand views and available information on the functioning of cell compartments at ultra-low temperatures and the mechanisms of nHDS action on female gametes.

Keywords: oocyte, vitrification, highly dispersed silica nanoparticles, functional activity of mitochondria, MitoTracker Orange CMTMRos, chromatin, Bos taurus. 